\title{
Nitric Oxide-Dependent Penile Erection in Mice Lacking Neuronal Nitric Oxide Synthase
}

\author{
Arthur L. Burnett, * Randy J. Nelson, ${ }^{\dagger}$ David C. Calvin, * \\ Jian-Xiang Liu,* Gregory E. Demas, ${ }^{+}$Sabra L. Klein, ${ }^{\dagger}$

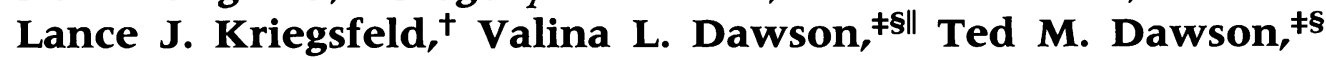 \\ and Solomon H. Snyder ${ }^{\boldsymbol{S}_{* *}}$ \\ *Department of Urology, The Johns Hopkins Hospital, Baltimore, \\ Maryland, U.S.A. \\ 'Department of Psychology, Behavioral Neuroendocrinology Group, \\ and Departments of ${ }^{\ddagger}$ Neurology, ${ }^{\S}$ Neuroscience, and "Physiology, \\ "Pharmacology and Molecular Sciences, and **Psychiatry and \\ Behavioral Sciences, The Johns Hopkins University, Baltimore, \\ Maryland, U.S.A.
}

\begin{abstract}
Background: Nitric oxide (NO) has been implicated as a mediator of penile erection, because the neuronal isoform of NO synthase (NOS) is localized to the penile innervation and NOS inhibitors selectively block erections. NO can also be formed by two other NOS isoforms derived from distinct genes, inducible NOS (iNOS) and endothelial NOS (eNOS). To clarify the source of NO in penile function, we have examined mice with targeted deletion of the nNOS gene (nNOS ${ }^{-}$mice).

Materials and Methods: Mating behavior, electrophysiologically induced penile erection, isolated erectile tissue isometric tension, and eNOS localization by immunohistochemistry and Western blot were performed on nNOS $^{-}$mice and wild-type controls.
\end{abstract}

Results: Both intact animal penile erections and isolated erectile tissue function are maintained in nNOS mice, in agreement with demonstrated normal sexual behaviors, but is stereospecifically blocked by the NOS inhibitor, L-nitroarginine methyl ester (L-NAME). eNOS is abundantly present in endothelium of penile vasculature and sinusoidal endothelium within the corpora cavernosa, with levels that are significantly higher in $\mathrm{nNOS}^{-}$mice than in wild-type controls.

Conclusions: eNOS mediates NO-dependent penile erection in $\mathrm{nNOS}^{-}$animals and normal penile erection. These data clarify the role of nitric oxide in penile erection and may have implications for therapeutic agents with selective effects on NOS isoforms.

\section{INTRODUCTION}

Nitric oxide (NO) participates in the tumoricidal and bactericidal actions of macrophages $(1,2)$, accounts for endothelial-derived relaxing factor

Address correspondence and reprint requests to: Solomon H. Snyder, Psychiatry and Behavioral Sciences, The Johns Hopkins University, 725 North Wolfe Street, Baltimore, MD 21205 , U.S.A.
(EDRF) activity $(3,4)$ and is a neuromodulator in the brain and peripheral nervous system $(5,6)$. Three distinct forms of NO synthase (NOS), derived from distinct genes have been identified and are designated inducible or macrophage NOS (iNOS; NOS-2), endothelial NOS (eNOS; NOS-3), and neuronal NOS (nNOS; NOS-1) (7). nNOS occurs in discrete neuronal popula- 
tions in the brain (8) and in the peripheral autonomic nervous system where it accounts for nonadrenergic, noncholinergic (NANC) transmission in various organs (3). For example, NANC stimulation results in intestinal relaxation which appears to involve NO; intestinal relaxation is blocked by NOS inhibitors and is mediated by the myenteric plexus neurons which contain nNOS $(9-12)$.

Penile erection involves relaxation of the smooth muscle of the corpora cavernosa by a NANC process $(13,14)$. NO has been implicated in studies showing that NANC relaxation of penile smooth muscle is abolished by NOS inhibitors (15-20). We demonstrated nNOS staining in the pelvic plexus, the dorsal penile nerve, the cavernous nerve, and its branches in the cavernous tissue $(21,22)$. Penile erection elicited in rats by electrical stimulation of the pelvic nerves is completely prevented by NOS inhibitors such as L-nitroarginine methyl ester (L-NAME) and by $\mathrm{N}$-methyl-L-arginine but not by N-methyl-D-arginine, which does not inhibit NOS activity $(21,22)$. Moreover, L-arginine administration restores erections, whereas D-arginine does not (21).

Recently mice with targeted disruption of nNOS have been developed (23). Gross locomotor activity, long-term potentiation in hippocampal slices (24) and long-term depression in cerebellar cultures (25) are normal in these animals. NO has been implicated in neural damage following vascular stroke, because stroke damage can be prevented with NOS inhibitors (5) and $\mathrm{nNOS}^{-}$mice are resistant to stroke damage (26). Breeding activity of nNOS ${ }^{-}$animals is superficially normal. If nNOS were fully responsible for penile erection, one might expect male mice to be impotent unless compensatory mechanisms occur. In the present study, we explore mating behavior as well as electrically induced penile erection. $\mathrm{nNOS}^{-}$mice display normal mating behavior and normal penile erection which is blocked by NOS inhibitors. We demonstrate a loss of nNOS from penile tissue of the nNOS ${ }^{-}$animals but describe a prominent eNOS system in penile tissue.

\section{MATERIALS AND METHODS}

\section{Mating Tests}

Adult male C57 BL6 and Agouti 129 (wild-type) and transgenic $\left(\mathrm{nNOS}^{-}\right)$mice were individually placed in a clear aquarium $(38.5 \times 26.5 \times 30.7$ $\mathrm{cm})$, with subjacent angled observational mirrors. Following a 15-min acclimation period, an estrous wild-type female was introduced into the mating arena. Mating behavior was recorded during a 30-min observation period by two independent observers who were unaware of the animals' genotype. Males were also paired with female C57 BL6 mice that were in natural estrus to assess fertility. Thus, behaviors (number of mounts, intromissions, and ejaculations) and fertility (number of pups sired) were recorded.

A mount was operationally defined as the male assuming the copulatory position, but failing to achieve intromission. Intromission was defined as the male's erect penis entering the vagina in association with thrusting behavior. Ejaculation was defined by the culmination of vigorous thrusting behavior and the male's arching his spine and lifting his forepaws off the female prior to penile withdrawal. Ejaculation was verified by the presence of a sperm plug followed by a refractory period of $\geq 5 \mathrm{~min}$ before the next mounting.

Stimulus females were ovariectomized and received subcutaneous placements of estradiol Silastic capsules. Mating tests commenced after a 2-week recuperation period. Six hours prior to the mating tests, the females were injected with $1 \mathrm{mg}$ of progesterone (suspended in sesame seed oil) to induce behavioral estrus. Mating tests began $8 \mathrm{hr}$ later at the onset of the dark period. Males participated in two separate mating tests, separated by 1 week.

\section{Physiologic Erection Studies}

Penile erections were electrically induced in intact adult male C57 BL6 and Agouti 129 (wildtype) and transgenic $\left(\mathrm{nNOS}^{-}\right)$mice following intraperitoneal pentobarbital anesthesia $(50 \mathrm{mg} / \mathrm{kg})$, as previously described in rats (21). Briefly, cavernous nerves arising from the ispilateral pelvic ganglion situated dorsal to the prostate were stimulated with unilaterally attached bipolar silver wire electrodes using a Grass S48 square wave stimulator at optimal parameters $(2 \mathrm{~V}, 5 \mathrm{msec}, 16 \mathrm{~Hz}, 60$ sec in duration). Neurostimulated erections were visually assessed and recorded at baseline and 10 min following the intracavernous administration of arginine derivatives (nitro-L-arginine methyl ester, nitro-D-arginine methyl ester, $20 \mathrm{mg} / \mathrm{kg}$ ).

\section{Isometric Tension Studies}

Isolated strips of corpus cavernosum (approximately $2 \times 2 \times 8 \mathrm{~mm}$ ) were excised from penes of adult male mice C57 BL 6 and Agouti 129 (wild-type) and transgenic (nNOS ${ }^{-}$) mice following $\mathrm{CO}_{2}$ inhalation. Strips were suspended in 
0.2-ml tissue chambers between two parallel platinum electrodes and bathed in Krebs physiologic salt solution (millimolar composition: $\mathrm{NaCl} 137$, $\mathrm{KCl}$ 5.9, $\mathrm{MgCl}_{2}$ 1.2, $\mathrm{CaCl}_{2} 2.5, \mathrm{NaHCO}_{3}$ 15.5, $\mathrm{KH}_{2} \mathrm{PO}_{4} 1.2$, glucose 11.5) with a mixture of $95 \%$ $\mathrm{O}_{2}$ and $5 \% \mathrm{CO}_{2}, \mathrm{pH} 7.2$, at $37^{\circ} \mathrm{C}$. The tissue was initially equilibrated and treated with $120 \mathrm{mM}$ Krebs solution (prepared by substituting $120 \mathrm{mM}$ of sodium with equimolar amounts of potassium) prior to achieving optimal resting isometric tension. Each strip was then precontracted with a supramaximal concentration of norepinephrine $(10 \mathrm{mM})$. Thereafter, each strip was subjected to electrical field stimulation $(10 \mathrm{~V}, 1$ msec, 10 -sec trains at 20,40,60 Hz) using a Grass S48 square wave stimulator at baseline and after sequential $15 \mathrm{~min}$ incubations with $1 \mu \mathrm{M}$ nitroL-arginine methyl ester and $1 \mathrm{mM}$ L-arginine. Tension was monitored by polygraph (Gould SC286, Gould Electronics, Valley View, $\mathrm{OH}$, U.S.A.). Tissue responses to chemical agents were quantified as percentages of the norepinephrine-induced tension.

\section{Western Blotting}

Whole penes were removed from adult male C57 BL6 and Agouti 129 (wild-type) and transgenic $\left(\mathrm{nNOS}^{-}\right)$mice and Sprague-Dawley rats following $\mathrm{CO}_{2}$ inhalation. Specimens were homogenized in ice-cold buffer $(50 \mathrm{mM}$ Tris $\mathrm{HCl}, \mathrm{pH}$ 7.4/1 mM EDTA/1 mM EGTA containing aprotinin $[2 \mathrm{mg} / \mathrm{ml}]$, leupeptin [ $5 \mathrm{mg} / \mathrm{ml}]$, and pefabloc $[1 \mathrm{mM}])$ and centrifuged at $10,000 \times g$ for 1 hr. Supernatants were analyzed for total protein (Coomassie protein assay reagent, Pierce, Rockford, IL, U.S.A.) and subjected to $7.5 \%$ SDS/ PAGE, transferred to Amersham Hybond-ECl nitrocellulose (Amersham, Arlington Heights, IL, U.S.A.) on a Millipore Milliblot semidry transfer system (Millipore, Marlborough, MA, U.S.A.) and probed overnight with a commercially available affinity-purified rabbit polyclonal antibody (1:250 dilution) against amino acids 1030-1209 of human eNOS (Transduction Laboratories). Blots were washed, developed by enhanced chemiluminescence (Amersham), and exposed to Kodak XAR film. To verify eNOS localizations, human endothelial lysate (Transduction Laboratories, Lexington, KY, U.S.A.) was used as a positive control. For preabsorption experiments, the antibody was preincubated with 50 -fold excess bovine eNOS peptide based on amino acids $1185-1205$ at $4^{\circ} \mathrm{C}$ for $24 \mathrm{hr}$. Intensities of the protein bands visualized roentgenographically were then measured using computer-assisted image analysis with comparisons made among samples run at identical exposures. eNOS protein was then quantified from homogenate supernatants using standard protein curves generated for each experiment from serial dilutions of human endothelial lysate in Laemmli buffer.

In separate experiments to verify the absence of nNOS immunoreactivity in $\mathrm{nNOS}^{-}$mice penes, blotting was performed using an affinitypurified rabbit polyclonal antibody (1:500 dilution) against a fusion protein corresponding to amino acids $1-181$ of rat nNOS (27). To evaluate iNOS immunoreactivity in $\mathrm{nNOS}^{-}$mice penes, blotting was performed using an affinity-purified rabbit polyclonal antibody (1:5000 dilution) against the 15 amino acid carboxy terminus of murine inducible NOS (gift from Dr. Charles Lowenstein, Johns Hopkins University) with murine macrophage lysate as a positive control.

\section{Immunohistochemistry}

Whole penes were removed from adult male C57 BL6 and Agouti 129 (wild-type) and transgenic $\left(\mathrm{nNOS}^{-}\right)$mice and Sprague-Dawley rats following $\mathrm{CO}_{2}$ inhalation. Specimens were divided into proximal and distal segments and quickly frozen. Transverse sections $(6-\mu \mathrm{m}$-thick) were cut on a cryostat $\left(-18^{\circ} \mathrm{C}\right)$ and mounted onto gelatin/ chrome alum-coated slides. Slide-mounted tissue sections were initially incubated in $4 \%$ freshly depolymerized paraformaldehyde in $0.1 \mathrm{M}$ phosphate-buffered saline (PBS), $\mathrm{pH} 7.4$, for $5 \mathrm{~min}$ and then permeabilized in $0.4 \%$ Triton $\mathrm{X}-100$ for $15 \mathrm{~min}$. All slides were subsequently incubated in PBS containing $1 \%(\mathrm{v} / \mathrm{v})$ normal goat serum for 20 min and then in PBS containing a commercially available affinity-purified rabbit polyclonal antibody, either anti-eNOS antibody ( $1: 50$ dilution) against amino acids 1030-1209 of human eNOS (Transduction Laboratories) or antieNOS antibody (1:250 dilution) against amino acids 599-613 of bovine eNOS (Biomol Laboratories, Plymouth Meeting, PA, U.S.A.) for $1 \mathrm{hr}$ at room temperature. Staining was visualized with an avidin-biotin-peroxidase system (Vector Laboratories, Burlingame, CA, U.S.A.) with diaminobenzidine as the chromogen. For controls, specimens were incubated with anti-eNOS antibody inactivated with serial dilutions of excess bovine eNOS peptide based on amino acids 1185-1205 at $4^{\circ} \mathrm{C}$ for $24 \mathrm{hr}$. As additional controls, specimens were processed in the absence of primary antibody. To verify endothelial staining, 
Factor 8 immunohistochemistry was also performed using anti-human von Willebrand factor antibody ( $1: 200$ dilution) (Sigma Chemical Co., St. Louis, MO, U.S.A.). The grade of eNOS immunohistochemical staining was compared between sections from wild-type and $\mathrm{nNOS}^{-}$mice prepared on the same slide by two independent observers.

In separate experiments to verify the absence of nNOS localizations in nNOS ${ }^{-}$mice penes, immunohistochemistry was performed using an affinity-purified rabbit polyclonal antibody (1:500) dilution against a fusion protein corresponding to amino acids $1-181$ of rat nNOS (27). To confirm NOS localizations, NADPH diaphorase histochemistry was performed by incubating slidemounted, fixed sections with $1 \mathrm{mM}$ NADPH and $0.2 \mathrm{mM}$ nitroblue tetrazolium in $50 \mathrm{mM}$ Tris $(\mathrm{pH} 7.4)$ and $12 \%(\mathrm{v} / \mathrm{v})$ dimethylsulfoxide for $30 \mathrm{~min}$ at room temperature.

\section{Statistics}

Where appropriate, results are expressed as mean values \pm standard error of the mean (SEM). Variables were evaluated by analysis of variance except for eNOS protein quantitations, which were analyzed as pairs between groups using the Wilcoxon signed rank test. Statistical differences were determined using Student's $t$ test.

\section{RESULTS}

\section{Mating Behavior and NO-Dependent Penile Erection Are Normal in nNOS $^{-}$Mice}

To evaluate mating behavior, wild-type and nNOS $^{-}$mice were paired with wild-type females in which estrus had been induced by progesterone administration to ovariectomized animals that had previously been primed with estradiol (Table 1). There is no difference between wild-type and $\mathrm{nNOS}^{-}$animals in the latency to first mount, the number of mounts of estrous females or any of the other monitored behavioral parameters observed (Table 1). Penile erections are clearly evident for each mouse displaying intromission.

Penile erections were elicited by electrical stimulation to the cavernous nerve of mice and monitored by observers who were uninformed to the genotype of the mice (Table 2). In both wild-type and nNOS $^{-}$animals nerve stimulation reliably produces full erections. Treatment with L-NAME completely prevents erections while $D$-NAME is ineffective, with no differences between wild-type and nNOS ${ }^{-}$animals.

\begin{tabular}{lcc}
\hline TABLE 1. Mating Test Observations* & \\
\hline $\begin{array}{l}\text { Behavior } \\
\text { (per } \mathbf{3 0} \text { min. test) }\end{array}$ & $\begin{array}{c}\text { Wild Type } \\
(\mathbf{n}=10)\end{array}$ & $\begin{array}{c}\text { nNOS- } \\
(\mathbf{n}=\mathbf{1 0})\end{array}$ \\
\hline Number of mounts & $21.7 \pm 2.7$ & $18.8 \pm 3.5$ \\
Number of intromissions & $11.1 \pm 3.5$ & $7.6 \pm 2.2$ \\
Number of ejaculations & $0.3 \pm 0.2$ & $0.3 \pm 0.2$ \\
Fertility & $\begin{array}{c}\text { Wild Type } \\
(\mathbf{n}=10)\end{array}$ & $\begin{array}{c}\text { nNOS- } \\
(\mathbf{n}=10)\end{array}$ \\
Number of pups sired & $\mathbf{8 . 5} \pm 0.5$ & $8.3 \pm 2.3$
\end{tabular}

*Parameters are expressed as mean \pm S.E.

To evaluate direct responses of the penile tissue, we examined effects of electrical stimulation upon isolated strips of corpus cavernosum (Fig. 1). L-NAME enhances the contractile effect of electrical stimulation, while L-arginine evokes relaxation. Responses to L-NAME and L-arginine are the same in wild-type and nNOS ${ }^{-}$tissue.

\section{Demonstration of eNOS in Penile Tissue}

The ability of the NOS inhibitor L-NAME to abolish erections in $\mathrm{nNOS}^{-}$animals in a stereospecific fashion and the retention of normal NOdependent contractile properties of corpus cavernosum tissue implies that the normal erections in $\mathrm{nNOS}^{-}$animals are subserved by NO. While Western blot analysis and immunohistochemistry have demonstrated a loss of nNOS in several tissues of the $\mathrm{nNOS}^{-}$animals, penile tissue had not previously been explored (23). Accordingly, we conducted Western blot analysis and immunohistochemical staining for nNOS in penile tissue of the nNOS ${ }^{-}$animals. The prominent band at $150 \mathrm{kD}$ characteristic of nNOS is present in penile tissue of wild-type mice but is completely absent in $\mathrm{nNOS}^{-}$animals, indicating the absence of nNOS in these animals (Fig. 2).

TABLE 2. Neurostimulated Penile Erections

\begin{tabular}{l|ccc}
\hline Strain & Baseline & D-NAME & L-NAME \\
\hline Wild Type & $12 / 12$ & $12 / 12$ & $0 / 12$ \\
nNOS- & $6 / 6$ & $6 / 6$ & $0 / 6$
\end{tabular}

D-NAME $=$ D-Nitroarginine methyl ester; L-NAME $=\mathrm{L}$ Nitroarginine methyl ester 


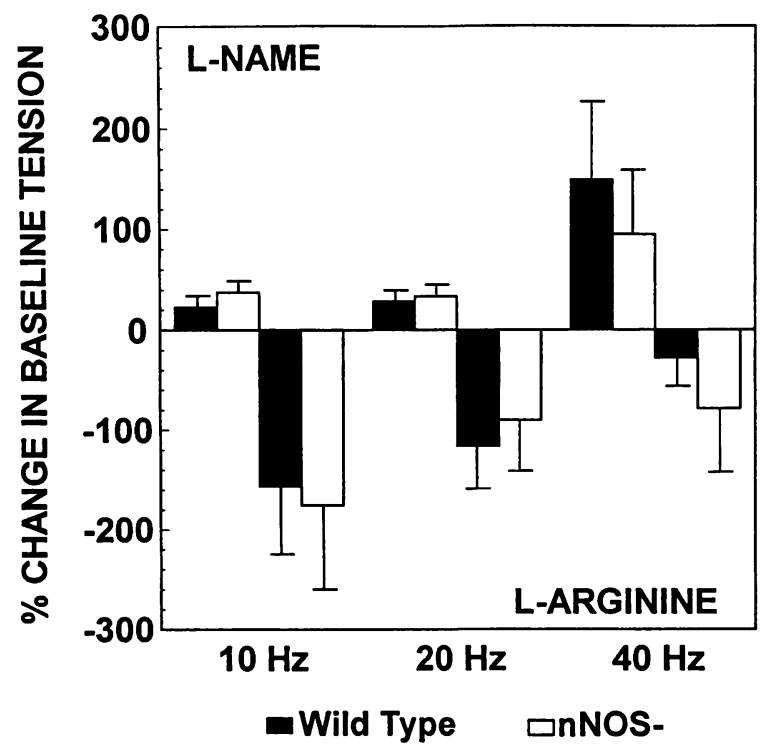

FIG. 1. Wild-type and nNOS ${ }^{-}$isolated corporal tissue tension effects following electrical field stimulation in response to the NOS inhibitor nitro-L-arginine methyl ester (L-NAME) and the NO precursor $L$-arginine

Equivalent contractile effects in the presence of $\mathrm{L}$ NAME and relaxant effects in the presence of L-arginine were observed for both groups at the frequencies shown. The data are expressed as means \pm SEM for six strips.

Immunohistochemical staining shows a localization of nNOS in wild-type mice to the dorsal penile nerve and its branches throughout the corpora cavernosa, essentially the same as observed previously in rats (21) (Fig. 3). The staining is not present in nNOS ${ }^{-}$animals.

If nNOS is not responsible for NO-mediated penile erection, the other two possibilities are iNOS and eNOS. We have failed to detect iNOS by Western blot analysis or immunohistochemical staining in penile tissue (data not shown). In Western blots of penile tissue we observe a prominent band for eNOS with a characteristic molecular weight of $135 \mathrm{kD}$ (Fig. 2). In seven replicate comparisons, we detect a consistent $20 \%$ increase in eNOS protein levels in nNOS ${ }^{-}$mice compared with wild-type mice (Figs. 2 and 4 ).

Immunohistochemical staining for eNOS reveals intense immunoreactivity in the endothelial layers of the dorsal penile arteries and vein (Fig. 5). The endothelial layer of the sinusoids of the corpora cavernosa stains prominently for eNOS. The epithelial lining of the urethra also stains for eNOS. The same staining pattern occurs with two different eNOS antisera raised against distinct peptide sequences. The identity of the endothelial layers is confirmed by staining with anti-

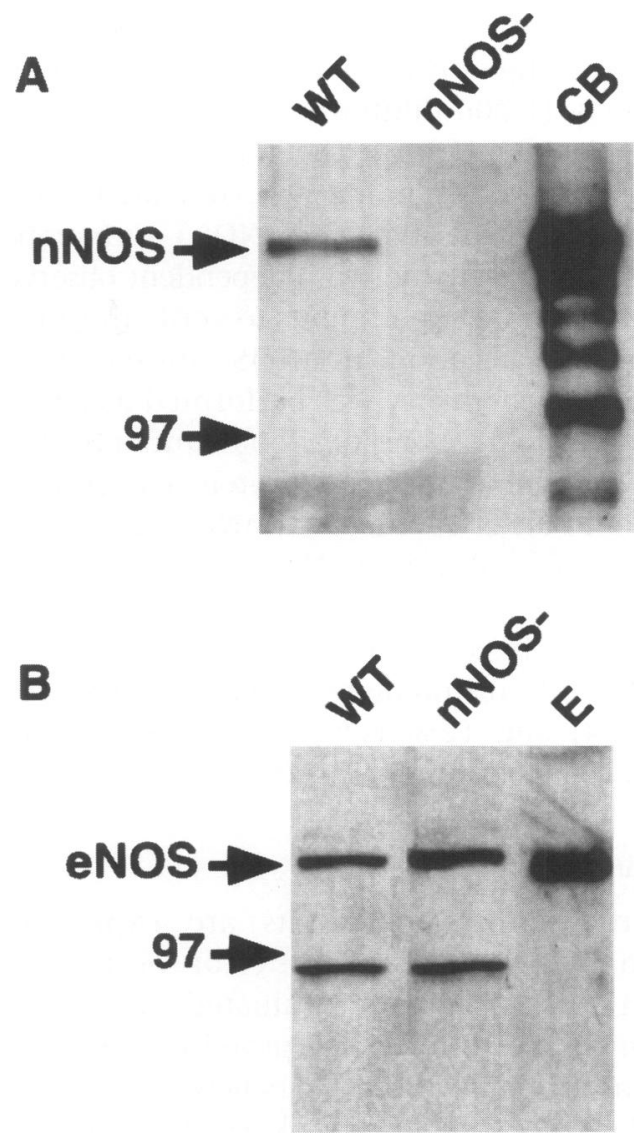

FIG. 2. Western blot analyses of penile homogenate supernatants from wild-type (WT) and nNOS ${ }^{-}$mice

In Panel A, a prominent band at $150 \mathrm{kD}$ corresponding to the molecular weight of nNOS is observed in the WT mouse penis but is absent in the nNOS ${ }^{-}$ mouse penis. Rat cerebellum (CB) serves as a positive control. In Panel B, prominent bands at $135 \mathrm{kD}$ corresponding to the molecular weight of eNOS are observed in both WT and nNOS ${ }^{-}$mouse penes. A greater amount of eNOS immunoreactivity is apparent in the $\mathrm{nNOS}^{-}$penis. Human endothelial lysate (E) serves as a positive control. Parallel secondary bands are also observed (B). Following preabsorption experiments, the characteristic NOS protein bands were abolished. For both blots, equivalent amounts of protein were loaded. Molecular sizes are indicated in $\mathrm{kD}$.

bodies to Factor 8 , which is exclusively associated with endothelium in various tissues (28). NADPH diaphorase staining, which reflects NOS catalytic activity (29-31), also displays localizations essentially the same as eNOS (data not shown).

To compare eNOS staining in wild-type and nNOS $^{-}$animals, two independent observers blindly evaluated nine distinct sections each from wild-type and nNOS ${ }^{-}$mice. In seven out of the nine paired comparisons of $\mathrm{nNOS}^{-}$and wildtype sections, eNOS staining was more prominent in $\mathrm{nNOS}^{-}$than wild-type animals. 


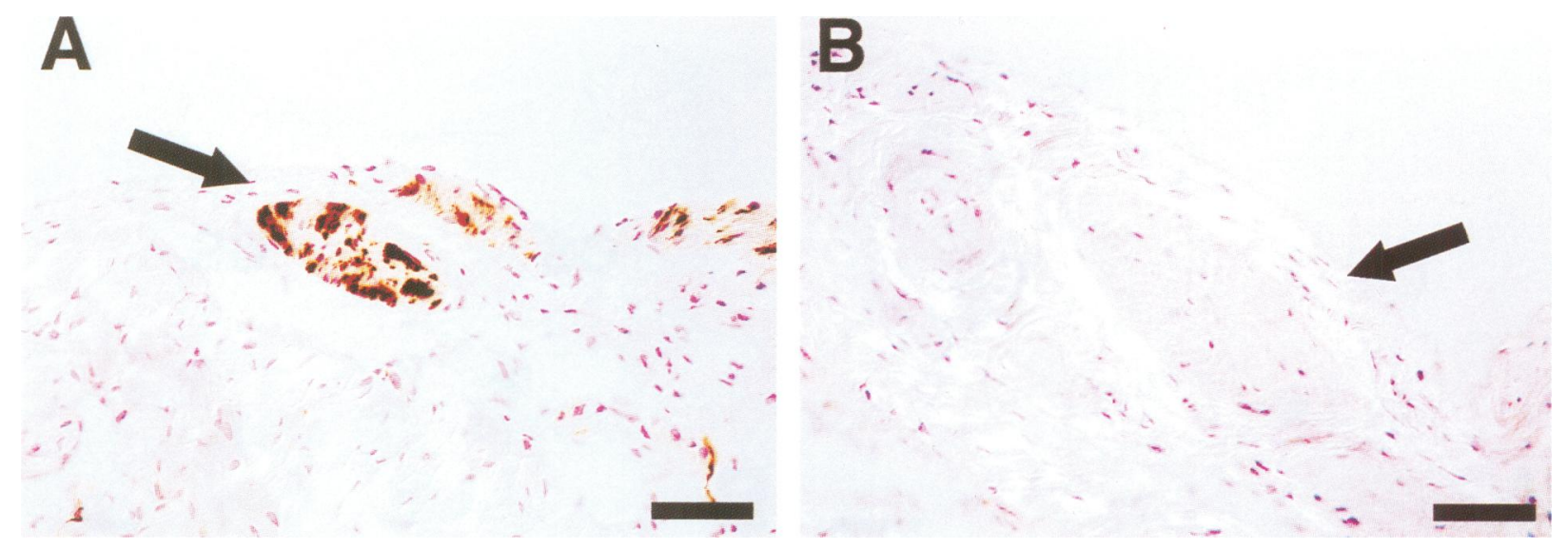

FIG. 3. Immunohistochemical localizations of nNOS in penes of wild-type and nNOS ${ }^{-}$mice $^{-}$

In cross sections of the proximal penis of the wild-type (A) and $\mathrm{nNOS}^{-}$mouse (B), staining of dorsal penile nerves (arrow) is observed only in the wild-type penis. Counterstaining with hematoxylin facilitates visualization. Scale bars $=100 \mu \mathrm{m}$.

\section{DISCUSSION}

The preservation of NO-dependent penile erection in nNOS $^{-}$animals suggests the involvement of eNOS. Penile erections in nNOS ${ }^{-}$animals are blocked stereospecifically by the nonspecific NOS inhibitor NAME. Moreover, L-NAME augments contractile responses of corpora cavernosa muscle and L-arginine reverses this effect in nNOS ${ }^{-}$ as well as wild-type animals.

The source of NO mediating penile erection in nNOS ${ }^{-}$animals does not appear to be iNOS, as we were unable to demonstrate its presence in penile tissue. By contrast, both Western blot and immunohistochemistry revealed abundant eNOS in penile tissue. There appears to be a consistent $20 \%$ increase in eNOS in $\mathrm{nNOS}^{-}$penile tissue compared with wild-type tissue. eNOS has previously been suggested to play a role in relaxation of penile smooth muscle $(16,18)$. Acetylcholine-induced relaxation of this muscle is reversed by NOS inhibitors $(16,18)$. NO donors relax penile smooth muscle (15). Moreover, eNOS localizations are consistent with a role in mediating relaxation of smooth muscle of the cavernosal sinusoids which is the fundamental process responsible for penile erection. It is well established that dilatation of penile arteries as well as the sinusoids is critical for erection, and eNOS occurs at both loci. Since penile erections occur in response to activation of the penile nerves, it would be important for nerve processes to release acetylcholine in the vicinity of the cell layers that contain eNOS. Neurons staining for choline acetyltransferase extend branches throughout the cavernosal tissue including the area of the endothelium $(32,33)$.
Thus, eNOS can account for NO-dependent penile erection in $\mathrm{nNOS}^{-}$animals. It is unclear whether nNOS or eNOS is primarily responsible for erection in wild-type animals. NOS inhibitors that have been employed do not differentiate between these two forms of the enzyme. The augmented eNOS activity in the nNOS ${ }^{-}$animals presumably represents a compensatory mecha-

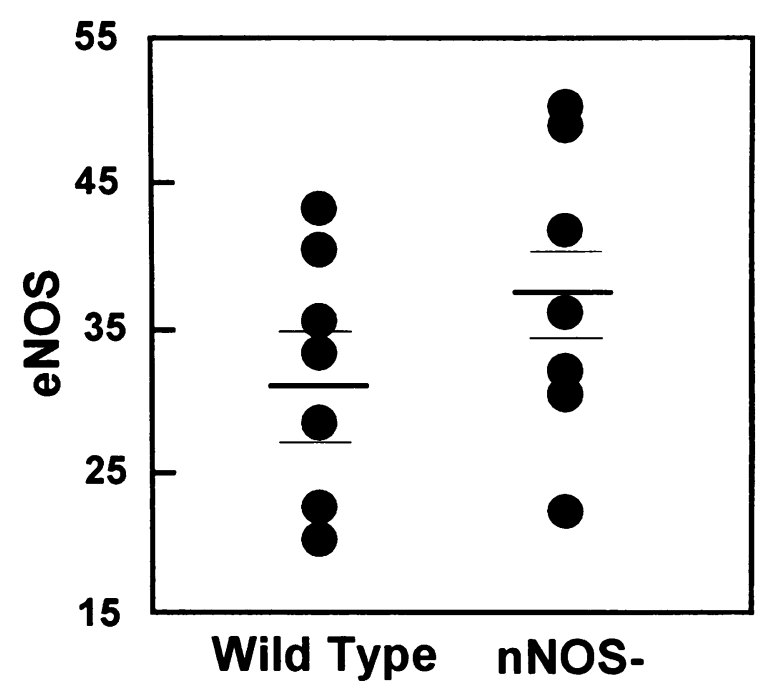

FIG. 4. Penile eNOS protein in wild-type and nNOS ${ }^{-}$mice

eNOS protein levels were derived from intensities of protein bands localized by Western blot analysis of penile homogenate supernatants, standardized for each experiment by serial dilutions of human endothelial lysate. The data are expressed as means (thick horizontal lines) \pm SEM (thin horizontal lines) for seven experiments. The amount of eNOS protein is significantly less in the wild-type group than in the nNOS $^{-}$group $(p<0.05)$. 


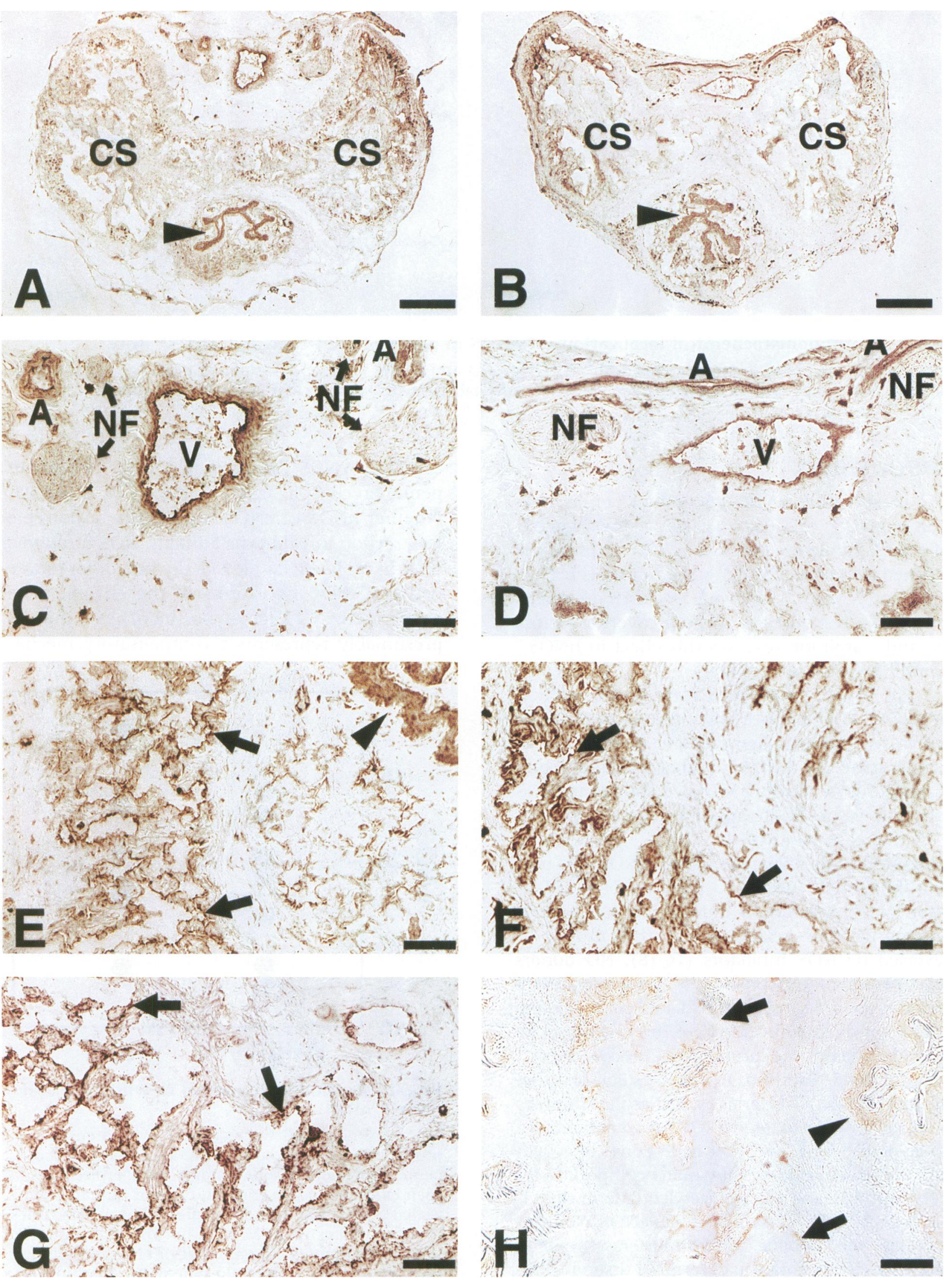


FIG. 5. Immunohistochemical localizations of eNOS in penes of wild-type and nNOS ${ }^{-}$mice $^{-}$

In cross sections of the proximal penis of the wild-type (A) and NOS $^{-}$mouse (B), staining is localized to the dorsal penile vasculature, peripheral regions of the corpora cavernosa, and the urothelium (arrowhead). Cavernous spaces (CS) are shown within the bilateral corpora cavernosa. Magnified views (C [from Panel A] and D [from Panel B]) show endothelial staining of the deep dorsal vein (V) and of dorsal arteries (A). A background level of staining is observed within dorsal penile nerve fibers (NF). In corresponding cross sections of peripheral regions of the distal penis, staining of the sinusoidal endothelium (arrows) is observed in the wild-type mouse penis (E) with a visibly increased staining intensity in the $\mathrm{nNOS}^{-}$mouse penis (F). In sections of the nNOS ${ }^{-}$mouse penis, Factor 8 immunohistochemical staining also localizes to sinusoidal endothelium (arrows; $(G)$ while preabsorption with eNOS peptide blocks eNOS endothelial localizations (arrows; $(\mathrm{H})$. eNOS immunoreactivity observed in urothelium (arrowheads; A, B, and E) is preabsorbed with eNOS peptide $(\mathrm{H})$. Scale bars in Panels A and B $=300 \mu \mathrm{m}$; and in Panels $\mathrm{C}-\mathrm{H}=100 \mu \mathrm{m}$.

nism, which might suggest that nNOS is principally involved in penile erection of wild-type animals. In support of this notion, removal of endothelial tissue does not affect NO-dependent relaxation of penile smooth muscle elicited by electrical stimulation (16).

In many instances of mice with targeted disruption of genes, compensatory mechanisms preserve the functions thought to be associated with proteins derived from the deviated genes. For example, cerebral vasodilatation induced by $\mathrm{CO}_{2}$ exposure is NO dependent, being abolished stereospecifically by NOS inhibitors and restored by L-arginine (34). The $\mathrm{CO}_{2}$ vasodilatation persists in $\mathrm{nNOS}^{-}$animals (35), but is no longer reversed by NOS inhibitors, implying compensation by some non-NO mechanism. The apparent maintenance of penile erection by eNOS in $\mathrm{nNOS}^{-}$animals may represent a unique instance in which compensation involves the same mediator derived from a separate gene.

\section{ACKNOWLEDGMENTS}

This work was supported by a New Investigator Grant from the American Foundation for Urologic Disease with funds contributed by G. D. Searle (ALB); USPHS Grants HD22201 and CA58618 (RJN); USPHS Grant DA-00266 and Research Scientist Award DA-0074 (SHS), USPHS CIDA NS-01578 and NS33277, the Paul Beeson Physician Scholars in Aging Research Program, and the International Life Sciences Institute (TMD); and USPHS Grant NS33142 (VLD).

\section{REFERENCES}

1. Nathan C. (1992) Nitric oxide as a secretory product of mammalian cells. FASEB J. 6: 3051-3064.

2. Marletta MA. (1993) Nitric oxide synthase structure and mechanism. J. Biol. Chem. 268: 12231-12234.
3. Moncada S, Higgs A. (1993) The L-argininenitric oxide pathway. N. Engl. J. Med. 329: 2002-2012.

4. Ignarro LJ. (1989) Endothelium-derived nitric oxide: actions and properties. FASEB J. 3: 31-36.

5. Dawson TM, Snyder SH. (1994) Gases as biological messengers: Nitric oxide and carbon monoxide in the brain. J. Neurosci. 14: 5147-5159.

6. Garthwaite J, Boulton CL. (1995) Nitric oxide signaling in the central nervous system. Annu. Rev. Physiol. 57: 683-706.

7. Bredt DS, Snyder SH. (1994) Nitric oxide: A physiologic messenger molecule. Annu. Rev. Biochem. 63: 175-195.

8. Bredt DS, Glatt CE, Hwang PM, Fotuhi M, Dawson TM, Snyder SH. (1991) Nitric oxide synthase protein and mRNA are discretely localized in neuronal populations of the mammalian CNS together with NADPH diaphorase. Neuron 7: 615-624.

9. Bult H, Boeckxstaens GE, Pelckmans PA, Jordaens FH, Van Maercke YM, Herman AG. (1990) Nitric oxide as an inhibitory nonadrenergic non-cholinergic neurotransmitter. Nature 345: 346-347.

10. Cocks TM, Angus JA. (1990) Comparison of relaxation responses of vascular and nonvascular smooth muscle to endothelium-derived relaxing factor (EDRF), acidified sodium nitrite (NO) and sodium nitroprusside. Naunyn Schmiedebergs Arch Pharmacol 341: 364-372.

11. Tottrup A, Svane D, Forman A. (1991) Nitric oxide mediating NANC inhibition in opossum lower esophageal sphincter. Am. J. Physiol. 260: G385-G389.

12. Desai KM, Sessa WC, Vane JR. (1991) Involvement of nitric oxide in the reflex relaxation of the stomach to accommodate food or fluid. Nature 351: 477-479.

13. Saenz de Tejada I, Goldstein I, Krane RJ. (1988) Local control of penile erection, nerves, 
smooth muscle and endothelium. In: Krane RJ (ed). Urol Clinic North America: Impotence. W. B. Saunders, Philadelphia, pp. 9-15.

14. Benson GS. (1983) Penile erection: In search of a neurotransmitter. World J. Urol. 1: 209212.

15. Ignarro LJ, Bush PA, Buga GM, Wood KS, Fukuto JM, Rajfer J. (1990) Nitric oxide and cyclic GMP formation upon electrical field stimulation cause relaxation of corpus cavernosum smooth muscle. Biochem. Biophys. Res. Commun. 170: 843-850.

16. Kim N, Azadzoi KM, Goldstein I, Saenz deTejada I. (1991) A nitric-oxide like factor mediates nonadrenergic-noncholinergic neurogenic relaxation of penile corpus cavernosum smooth muscle. J. Clin. Invest. 88: 112-118.

17. Pickard RS, Powell PH, Zar MA. (1991) The effect of inhibitors of nitric oxide biosynthesis and cyclic GMP formation on nerve evoked relaxation of human cavernosal smooth muscle. Br. J. Pharmacol. 104: 755759.

18. Knispel HH, Goessl C, Beckman R. (1991) Basal and acetylcholine-stimulated nitric oxide formation mediates relaxation of rabbit cavernous smooth muscle. J. Urol. 146: 1429-1433.

19. Rajfer J, Aronson WJ, Bush PA, Dorey FJ, Ignarro LJ. (1992) Nitric oxide as a mediator of the corpus cavernosum in response to nonadrenergic noncholinergic transmission. N. Engl. J. Med. 326: 90-94.

20. Holmquist F, Hedlund $\mathrm{H}$, Anderson KE. (1992) Characterisation of inhibitory neurotransmission in the isolated corpus cavernosum from rabbit and man. J. Physiol. 449: 295-311.

21. Burnett AL, Lowenstein CJ, Bredt DS, Chang TSK, Snyder SH. (1992) Nitric oxide: A physiologic mediator of penile erection. Science 257: 401-403.

22. Burnett AL, Tillman SL, Chang TSK, et al. (1993) Immunohistochemical localization of nitric oxide synthase in the autonomic innervation of the human penis. J. Urol. 150: 73-76.

23. Huang PL, Dawson TM, Bredt DS, Snyder SH, Fishman MC. (1993) Targeted disruption of the neuronal nitric oxide synthase gene. Cell 75: 1273-1286.

24. O'Dell TJ, Huang PL, Dawson TM, et al. (1994) Blockade of long-term potentiation by inhibitors of nitric oxide synthase in mice lacking the neuronal isoform suggests a role for the endothelial isoform. Science 265: 542.

25. Linden DJ, Dawson TM, Dawson VL. (1995) An evaluation of the nitric oxide/cGMP/ cGMP-dependent protein kinase cascade in the induction of cerebellar long-term depression in culture. J. Neurosci. 15: 5098-5105.

26. Huang Z, Huang PL, Panahian N, Dalkara T, Fishman MC, Moskowitz MA. (1994) Effects of cerebral ischemia in mice deficient in neuronal nitric oxide synthase. Science 265: 1883-1885.

27. Roskams AJ, Bredt DS, Dawson TM, Ronnett GV. (1994) Nitric oxide mediates the formation of synaptic connections in developing and regenerating olfactory receptor neurons. Neuron 13: 289-299.

28. Koutts J, Howard MA, Firkin BG. (1974) Factor 8 physiology and pathology in man. Semin. Hematol. 11: 115-145.

29. Dawson TM, Bredt DS, Fotuhi M, Hwang PM, Snyder SH. (1991) Nitric oxide synthase and neuronal NADPH diaphorase are identical in brain and peripheral tissues. Proc. Natl. Acad. Sci. U.S.A. 88: 7797-7801.

30. Hope BT, Michael GJ, Knigge KM, Vincent SR. (1991) Neuronal NADPH diaphorase is a nitric oxide synthase. Proc. Natl. Acad. Sci. U.S.A. 88: 2811-2814.

31. Dinerman JL, Dawson TM, Schell MJ, Snowman A, Snyder SH. (1994) Endothelial nitric oxide synthase localized to hippocampal pyramidal cells: Implications for synaptic plasticity. Proc. Natl. Acad. Sci. U.S.A. 91: 4214-4218.

32. Shirai M, Sasaki K, Rikimaru A. (1972) Histochemical investigation on the distribution of adrenergic and cholinergic nerves in human penis. Tohoku J. 107: 403-404.

33. Gu J, Polak JM, Islam KN, et al. (1983) Peptidergic innervation of human male genital tract. J. Urol. 130: 386-391.

34. Irikura K, Maynard KI, Lee WS, Moskowitz MA. (1994) L-NNA decreases cortical hyperemia and brain cGMP levels following $\mathrm{CO}_{2}$ inhalation in Sprague-Dawley rats. Am. $J$. Physiol. 267: H837-H843.

35. Irikura K, Huang PL, Ma JL, et al. (1995) Cerebrovascular alterations in mice lacking neuronal nitric oxide synthase gene expression. Proc. Natl. Acad. Sci. U.S.A. 92: 68236827. 